American Journal of Pharmaceutical Education 2020; 84 (8) Article 8142.

\title{
COMMENTARY
}

\section{Perspective from a Teaching and Learning Center During Emergency Remote Teaching}

\author{
Lauren S. Schlesselman, MA Ed Psych, PharmD \\ University of Connecticut, Center for Excellence in Teaching and Learning, Storrs, Connecticut \\ Associate Editor, American Journal of Pharmaceutical Education, Arlington, Virginia
}

Submitted May 6, 2020; accepted May 11, 2020; published August 2020.

\begin{abstract}
During the COVID-19 pandemic, universities around the globe frantically and emergently switched to remote teaching. This commentary provides the perspective from a teaching and learning center about the difference between emergency remote teaching and online learning, plus suggestions for preparing for an online fall semester.
\end{abstract}

Keywords: online learning, remote teaching, technology

In teaching and learning centers across the globe, faculty developers, instructional designers, and educational technologists have spent the last few months frantically assisting faculty, staff, and graduate students to make the shift to emergency remote teaching. They offered workshops, provided one-on-one consultations, developed resources, and troubleshot issues. However, this is what teaching and learning centers always do. The last few months have simply required them to assist more faculty members more quickly. Just one of our educational technologists at the University of Connecticut Center for Excellence in Teaching and Learning offered 50 workshops attended by 1650 faculty staff members and graduate students over a six-week span during the 2020 spring semester. In contrast, across the entire teaching and learning center, we typically train 2000 individuals annually.

Centers for teaching and learning around the globe have enjoyed the opportunity to work with and train thousands of faculty members, staff members, and graduate students over the last six months. However, in recent conversations with these colleagues, they have all expressed the same desire as we move forward: to advance learning through better teaching. As Ackoff and Greenberg so aptly point out in Turning Learning Right Side $U p$, "the objective of education is learning, not teaching." Some of you have probably heard my story about the cartoon I had hanging outside my office in which one boy tells the other boy he taught his dog to whistle but when the second boy points out that the dog is

Corresponding Author: Lauren S. Schlesselman, University of Connecticut, Center for Excellence in Teaching and Learning, 368 Fairfield Way U-4001, Storrs, CT. Tel: 860486-3402. Email: Lauren.schlesselman@uconn.edu not whistling, the first one says something along the lines of, "I said I taught him; I did not say he learned." One day I heard two students in the hallway discussing the cartoon and theorizing about what it meant. One student thought it was my way of saying that I felt students were too ignorant to learn anything that is taught to them. Conversely, the other student thought it was my way of saying that I felt faculty members were too incapable to teach in a way that allowed students to learn. Too bad for the students, but I was sitting in my office listening to their conversation. This prompted me to invite them in for a discussion about the real meaning behind the cartoon. They probably rue the day they had to listen to me explain that teaching and learning are two different concepts. As the cartoon demonstrates, simply because teaching occurred does not guarantee learning did. Conversely, learning can occur without the need for teaching because the learner can gain knowledge, skills, and attitudes through experience or by studying. Therefore, teaching is not the most important aspect of learning, so the student, rather than the instructor, should remain the focus of the learning environment.

While technology provided the ability for schools and colleges to transition to teaching online during the spring 2020 semester, what was provided for the remainder of the semester was emergency remote teaching, not online learning. Teaching and learning centers observed faculty members pretending nothing had changed and attempting to transition their course without making revisions to it. Some faculty members even asked how to provide a three-hour synchronous lecture or three-hour asynchronous video. Even during the best of times, neither of these is ideal without including activities during that time that require significant student engagement with 


\section{American Journal of Pharmaceutical Education 2020; 84 (8) Article 8142.}

the content. During remote teaching, relying on synchronous attendance proves especially challenging because of technology, connectivity, accessibility, and time zone issues.

In contrast to emergency remote teaching, online learning is bound by many standards to ensure optimal learning. Online learning provides opportunities for community building among students and with the instructor; opportunities for learner engagement with the material through realistic practice, spaced repetition, realworld context, and feedback; and opportunities for faculty members to support learners. Online learning focuses on achieving learning objectives rather than simply covering content. Online learning also creates a safe environment that addresses the needs of all learners, including accessibility. Even with courses that they have taught face-toface for years, it usually takes the faculty members who work with our instructional designers six months to create an online course that meets all of the standards established by Quality Matters (www.qualitymatters.org), an online peer-review process for course design.

Over the years, numerous faculty members have commented that they "do not believe in online teaching." The two most common reasons expressed for this belief are that students will not learn that way and that students are not engaged. Research has shown that these concerns are unfounded. In the US Department of Education's meta-analysis of online learning, researchers found that students in online courses performed better than those who learned face to face. ${ }^{2}$ The researchers also found that this increase in student learning was associated with more time spent on task with online learning. ${ }^{2}$ They also found the effect size was larger when online learning was collaborative or instructor-led rather than independent. ${ }^{2}$ In research analyzed by Thalheimer, he found that it is the teaching method rather than the modality that produces the difference in learning outcomes. If the learning method is held constant, then online learning and face-toface learning produce equal results. However, when the learning experience is designed for online learning then the outcomes are better with online learning than with face-to-face learning. ${ }^{3}$

In reality many institutions will face a fall and perhaps spring semester that is either fully or partially online. Now is the time to prepare. What was acceptable as emergency remote teaching will not be appropriate for an online fall semester. Rather than attempting to replicate face-to-face lectures using technology, quality online courses require engaging students with the content, fostering collaboration, and creating community. As any teaching and learning center will tell you, while there are many steps in creating an online course, the first step in preparing for an online course is to clearly define measurable learning objectives. Another important aspect of designing an online course is being flexible. An online course will not look identical to a face-to-face class. Online courses tend to be even more engaging and interactive than a face-to-face class so students will interact heavily with the instructor, the other students, and the content in a meaningful way. Flexibility in the types of assessments incorporated in the course is also encouraged with the addition of more formative assessments and projects.

If an online fall semester is mandated, flexibility will also be needed with students who continue to have technology, connectivity, time zone, and mental health challenges. Technology will be a larger component of your online course, so as you select technology tools to support instructor-to-student and student-to-student collaboration and interaction, find a colleague with whom to practice using the technology before trying it with students. Now is also the time to acquire or produce any videos made to share content. Videos should be short (ideally less than six minutes), ${ }^{4}$ engaging, and preferably include video of the instructor on the screen in addition to content. All videos must be captioned, not just for students who need this accommodation but to benefit all students. Asynchronous course content is preferred for online courses to allow students the opportunity to watch it when they have connectivity and to re-watch it to deepen learning. Synchronous activities should be restricted to collaboration among students and one-on-one or small group discussions between students and faculty member during office hours.

During the chaotic shift to emergency remote learning, many of you may have turned to your teaching and learning centers as a source of pedagogical and technological knowledge and skill. As we have heard from many of the faculty members we have worked with over the last few months, you may have been surprised and impressed by the amount of knowledge and expertise contained within the center. If you have not been routinely availing yourself of the support offered by your institution's teaching and learning, why not? As a faculty friend of mine likes to point out, being a faculty member is the job you did not train for. Most of your training prior to your first academic position related to your discipline. Training for best practices and theories related to teaching was often limited or nonexistent. Many faculty members we work with have admitted that they simply replicated what they had experienced as a student even if they felt it had not been an effective learning experience. Teaching and learning center staff members are trained on best practice and theory, so take advantage of what they have to offer. 


\section{American Journal of Pharmaceutical Education 2020; 84 (8) Article 8142.}

The goal of teaching and learning centers is to advance student learning; therefore, they would be happy to have you seek their assistance to ensure you have an effective online course rather than continue with emergency remote teaching.

\section{REFERENCES}

1. Ackoff R, Greenberg D. Turning Learning Right Side Up: Putting Education Back on Track. Upper Saddle River, NJ: Wharton School Publishing; 2008.

2. US Department of Education. Evaluation of evidence-based practices in online learning: a meta-analysis and review of online learning studies. https://www2.ed.gov/rschstat/eval/tech/evidencebased-practices/finalreport.pdf Published September 2010. Accessed August 12, 2020.

3. Thalheimer W. Does eLearning work? What the scientific research says! Work-Learning Research website: https:// www.worklearning.com/wp-content/uploads/2017/10/DoeseLearning-Work-Full-Research-Report-FINAL2.pdf Published 2017. Accessed August 12, 2020.

4. Guo PJ, Kim J, Rubin R. How video production affects student engagement: an empirical study of MOOC videos. Conference proceeding of the ACM Conference on Learning, March 2014: http:// up.csail.mit.edu/other-pubs/las2014-pguo-engagement.pdf. Accessed August 12, 2020. 